\title{
Sayyid Qutb's political and religious thought: the transformation of jahiliyyah and the implications for Egyptian democracy
}

\author{
Mark A. Menaldo* \\ Assistant Professor, Political Science, Texas A\&M International University, Laredo, TX, USA
}

\begin{abstract}
Sayyid Qutb is one the twentieth century's most influential Muslim thinkers and one of the ideological founders of the Muslim Brotherhood. This essay surveys the context which shaped his political and ideological ideas and activities and the history of the Muslim Brotherhood in Egypt. In addition, it pays close attention to Qutb's critical reinterpretation of classical Islamic ideas jahiliyyah and hakimiyyah. Through these concepts Qutb articulates a radical division of the world into Muslim and non-Muslim societies, while posing an alternative to secular notions of sovereignty. This essay follows up on the influence of these ideas by discussing how Egypt's current political climate reveals the schism between the Muslim Brotherhood's vision of Islam and liberal democratic politics.
\end{abstract}

Keywords: Sayyid Qutb, political thought, Islamic ideology, Muslim Brotherhood

\section{INTRODUCTION}

In 2011-2012, the Arab Spring and toppling of autocratic governments in the Middle East brought the issue of leadership and religion into sharp focus. Nowhere is this more evident than in Egypt, where the newly democratic government dominated by the Muslim Brotherhood has become an example of the difficulties confronting religiously inspired rule in a democratic state. The Muslim Brotherhood, an insular Islamic organization that was founded in 1928 and existed precariously through the regimes of Gamal Abdel Nasser and Hosni Mubarak. After Egypt erupted in a popular revolution that toppled Mubarak's regime in 2011, voters elected Brotherhood candidates into a large share of parliamentary seats as well as the presidency. Almost precisely a year later, popular dissatisfaction with the rule of the Muslim Brotherhood caused its overthrow by the military.

As of this writing, the eventual outcome of the Egyptian unrest remains unclear. Regardless of the resolution of Egypt's democratic crisis, however, the emergence of the Muslim Brotherhood as a potent political force in Egypt raises important questions about how a party devoted to Islamic principles can mesh with a polity dedicated to democratic ideals. As the fledgling democracy deals with constitutional crises and the reaction to the broadening of President Mohamed Morsi's executive powers, the

\footnotetext{
* I thank Mohamed Ayoob for introducing me to the study of Islam and politics and for supporting me in my research of Sayyid Qutb. I would also like to thank the anonymous reviewers for their careful review of this manuscript and providing me with their comments and suggestions that have greatly improved its quality.
} 
question for the country is how to integrate into its democracy the large segment of the population devoted to the principles of the Muslim Brotherhood.

Consideration of these questions can be aided by a closer examination of the intellectual foundation of the Muslim Brotherhood. In this paper, I explore the political philosophy of Sayyid Qutb, the most prominent intellectual and ideological leader of the Brotherhood in the last 50 years. Qutb's life and political thought can be studied through his different stages of personal transformation, which parallel the developments in the Muslim world as a whole. Most important, his thought is marked by a radical shift from a secular and literary perspective to an intellectual and political engagement with Islam in the early 1950s. The second stage of Qutb's thought occurred in the last decade of his life, which he spent in prison, and it was during this time that his most radical Islamic ideas emerged.

Qutb is not only an intellectual and ideological founder of the modern Muslim Brotherhood but also of the global jihad movement. Within a few years of 9/11, Qutb was described in the American media as Al-Qaeda's 'philosopher of terror', as put famously, yet superficially, by Paul Berman in the New York Times magazine (2003). However, Qutb is a much more complex figure, and his influence on today's jihadist movement requires a close inspection of what he writes on the subject of jihad.

Specifically, Qutb has reinterpreted the classical Islamic ideas jahiliyyah (traditionally thought of as the age of ignorance of God) and hakimiyyah (sovereignty), which form the cornerstone of his thought. Qutb's redefinition of jahiliyyah serves as the main philosophical defense for Muslim groups against what they perceive as the encroachment of Western political and moral principles on Islam. The condition of jahiliyyah, in which Allah is not held as the ultimate sovereign, is a state of kufr (unbelief). Faith alone is not sufficient for Islam, as Qutb argues that it is a universal system that integrates the experience of divine and practical affairs.

Of interest for scholars of politics and leadership is how Qutb's understanding of hakimiyyah and jahiliyyah not only critique secular sources of authority, but also 'form the ideological and political tactics of many of the Islamic political organizations worldwide' (Khatab 2006a, p. 1). As Qutb's multifaceted understanding of jahiliyyah evolved over the course of his lifetime, I concentrate on what Sayed Khatab refers to as the 'fourth stage' in Qutb's development of the theory of jahiliyyah, in which the theological, philosophical, and political dimensions are fully fleshed out.

In addition, I seek to explain Qutb's idea of the tension between jahiliyyah and hakimiyyah by contrasting it with Thomas Hobbes's idea of sovereignty. As Ronald A.T. Judy (2004) has powerfully articulated, the comparison between Qutb's and secular liberalism's (mainly Hobbes's) notions of sovereignty helps illuminate Qutb's 'realist science,' which Judy refers to as his synthesis of the Islamic system, the material world, and liberty of consciousness (pp. 119-120). Lastly, I contend that Qutb's prescription for jahiliyyah is jihad. He argues against what he considered an apologetic framing of jihad as a defensive war. In his reclaiming of jihad, Qutb proposes that the idea is best thought of as 'struggle,' as the term is understood in English. Jihad is a universal movement that strives to replace jahili (un-Islamic) societies with a universal Islamic system.

While the Prophet fought the phenomenon of jahili against non-Muslim forces that beset him and his followers, Qutb insists that a perpetual jihad is necessary in order to fight the jahili of the modern world. Although Qutb advocates for a universal jihad movement, individuals who understand him as the philosopher of jihad have misunderstood his more intricate ideas. In my view, Qutb's endorsement of jihad is not the radical aspect of his political thought. Rather, what is transformative is his novel 
interpretation of jahiliyyah, which led him to the conclusion that Islam must wage a jihad against forces that impede its true practice.

It is Qutb's refashioning of jahiliyyah that makes his thought alarming to liberal thinkers since it completely rejects Western ideals and liberal politics. As such, Qutb's current followers cannot accommodate democratic principles such as legal pluralism and shariah ('spirit of Islam') as they would not accept the view that shariah is one legal system among many. Rather they would see it as part of a human and institutional manifestation of $\operatorname{din}$ (religion). Qutb understands human nature and Islamic law as complements to each other. The Islamic system is a unity, which he contrasts with the fractured reality of secular systems.

The paper is divided into two halves. In the first half, I describe Egypt's influential leaders who tried to balance the needs of modernity and Islam. This historical snapshot provides a context for Qutb's life, which I explore as a set of stages that influenced both his thought and political activity. In the second half, I turn to Qutb's writings. First I explain the conceptual frameworks for his interpretation of Islam as a system and then closely inspect the ideas hakimiyyah and jahiliyyah. These principles provide the grounds for Qutb's rationale for jihad, which I examine last.

\section{EGYPT AND ISLAM: MAJOR FIGURES OF THE MODERN AGE}

In the late nineteenth century, Britain increased its footprint in Egypt; it had won a majority stake to control the Suez Canal and became the dominant Western power in Egypt when it occupied the country in 1882. Elite Egyptians welcomed modernization in material and social terms, while moderate reformers wanted to keep modernity's benefits and Islam separate.

Jamal al-Din Afghani, the immensely influential father of Islamic modernism, desired that the movement in Egypt follow an Islamic blueprint, since he believed that Western ideas and social mores threatened the faith. During his time in Egypt from 1871 until his expulsion in 1879, Afghani viewed Egypt's first foray into modernization as flawed because it was based on process imitation and importation, which would inevitably create a much wider gulf between Arab and Western countries. When he traveled to Europe, he criticized how Western societies based their organization on material power: economic, political, and technological. He believed that Islamic societies should promote economics, politics, and technology in a way that would agree with Islamic practice without accepting Western ideals - an approach that would lead to a revival of Islamic civilization (Keddie 1983).

For Afghani, Egypt's accommodation of Western ideas and colonialism was problematic because an insurmountable gap existed between the Islamic worldview and the West's scientific anthropocentricism. The West's rationalization and secularization led to what Max Weber called the 'disenchantment of the world,' which hastens the end of belief and tradition. Reformers like Afghani tried to envision technological and scientific change as something that would complement Islamic culture. Afghani attracted an extensive following through rhetorical eloquence and a powerful personality. A master teacher, he adapted to the temperament of his audiences and thus 'could weld the rationalist elite and the more religious masses into a common political movement' (Keddie 1972, p. 87).

Muhammad Abduh, Afghani's most important disciple, called for religious reform in order to achieve a total overhaul of Islamic and Egyptian society. Abduh believed that a correct interpretation of the Qu'ran showed that Islamic doctrine was conducive to great economic and social advancement. He joined together with Afghani's 
refutation of Western imperialism and advocated for scientific investigation on Islamic terms. Like Afghani, Abduh called for a return to the spirit of early Islam, which used rationalism to free Islam from rigid structures of Islamic culture (Sedgwick 2010). He embarked on a religious movement that fostered educational, political, and shariahcourt reform as well as gender equality (Khan 2012). However, Abduh was routinely opposed by the more conservative groups that were deeply skeptical of non-traditionalist education and reformist ideas.

In the early decades of the twentieth century, after moderate reformers such as Afghani and Aduh, Egypt saw the rise of diverse political groups, the most prominent being the secularized Egyptians, liberal Muslim reformers, and Muslim reactionaries. Of equal importance was the Salafiyyah religious movement, a reactionary faction that was antipathetic to Western liberalism and Sufism. This particular group had experienced modernity's disenchantment to a higher degree, were prone to reject science and modernity outright because of their inability to espouse a sense of the sacred (Armstrong 2000, p. 160). The contested political and religious terrain facing Egyptian society in the early twentieth century served as the backdrop for the rise of the Muslim Brotherhood's founder, Hassan Al-Banna.

In 1927, the government appointed Al-Banna a teacher, and in 1928 he inaugurated the Muslim Brotherhood with six of his disciples. Established as a revitalization movement, the Brotherhood soon became a politico-religious organization. The Brotherhood combined its religious objectives with a thorough program of social and economic reform. By the mid 1930s, the Brotherhood had become increasingly politicized as it challenged other political groups and held rallies and demonstrations demanding the implementation of sharia law (Rubin 2010, p. 40). Al-Banna's grand personality defined the Brotherhood as an organization, as his charismatic leadership attracted adherents who obeyed him absolutely. As a result, it institutionalized a top-down distribution of power despite the fact that many factions existed and still exist today.

A unique individual, Al-Banna to this day is depicted by the Brotherhood as no ordinary mortal (Pargeter 2010). As an administrator, teacher, and political activist, he exuded an exuberant vitality, inexhaustible energy, and a prodigious memory. Without respite, Al-Banna taught, wrote, and toured the lecture circuit while supervising the Brotherhood's activities. His supporters were touched by his charm, magnetism, and eloquence in speech, which helped legitimate his authority. Moreover, Al-Banna's disciples could find substantial intellectual sustenance in his ideas. He studied logic, psychology, and history, and drew on his knowledge of subversive medieval Islamic movements, the psychological warfare of esoteric heterodox Muslim sects, and Sufism.

Al-Banna's legacy as the Brotherhood's near-mythic founder rests not on his intellectual pursuits but rather on his organizational talents. He recruited a great number of young Egyptians into the Brotherhood and quickly grew the organization. However, he did not impart a guiding philosophy. It was in this context, in which the group lacked a clear political philosophy, that Qutb emerged as the Brotherhood's second, and more controversial, leading figure.

\section{SAYYID QUTB'S LIFE: AN INTELLECTUAL AND POLITICAL JOURNEY}

Sayyid Qutb was born in 1906 in the village of Mosha, where he received a traditional Quranic education. Qutb showed promise at an early age by memorizing the Qu'ran as a child, which compelled his parents to move the family to Cairo, where he entered the preparatory school Tajhizyah Dar al-Ulum. His early education enabled him to enroll 
in 1929 at Dar al-Ulum (University of Cairo), from which he finished his studies in 1933. On graduation, Qutb was appointed as a lecturer, given his prominent status as a literary critic. His book The Poet's Responsibility in Life had been published in 1933. Shortly after, he was appointed inspector of schools by the Ministry of Education, a post he held until 1939.

Qutb had a penchant for literature and poetry, and his early writings, consisting of poetry, essays on education, autobiographies, literary criticism, and love stories, were secular in nature. In his writing, he experimented with existentialism, individualism, and liberalism. During his tenure as a teacher, he behaved as the university's gadfly. A vocal critic of political conditions in Egypt, Qutb routinely found himself at odds with the school officials. On many occasions, Qutb tried to quit his job as inspector of schools, and in one instance he actually did quit and took a position as the editorin-chief of two journals; yet these periodicals were later banned because of their political character. Notwithstanding his tenuous position in politics, in 1948 he was asked by the Ministry of Education to travel to the US to study modern systems of education.

Over a 2-year period, he worked in several institutions, including the Wilson Teachers' College in Washington, DC; Colorado State College for Education in Greeley; as well as Stanford University. A watershed moment in his life, Qutb's trip represents his decisive experience with the West, which catalysed his conviction that only Islam can answer the fundamental question of how one should live one's life and how society should be organized. Social Justice in Islam was published while he was in the US. On his return to Egypt, he published the article 'The America I Have Seen,' in which he addresses three pervasive features of what he believed constituted the core of American life: materialism, racism, and sexual permissiveness. Qutb viewed the American soul as characterized by acquisitiveness, a phenomenon Alexis de Tocqueville had observed a century earlier. This individual industriousness was aimed at material gain and not moral and spiritual well-being.

In Qutb's mind, American materialism trumped the moral good and inspired a general restiveness and a subtle melancholy in society. As such, acquisitiveness spurred by ambition and longing to rise in social position led to American's lack of tranquility and moral standards. Qutb viewed the West's political and moral system as regressive, save for technological innovation. Despite his literary forays into individualism and liberalism, he concluded that individual freedom and secular politics drove Americans toward Epicureanism. For Qutb, the solution to this debased form of human life lay in the return to God and Islam as universal religion.

Qutb explored America and treated his time there as a sociological experiment. He was aware of the ubiquity of American religiosity, so he frequented churches. However, he perceived this religiosity as merely fit for socializing and intra-group competition. Religious practice simply reproduced the entrenched malignity of materialism. Various sects and churches were differentiated in terms of wealth and status, while worship seemed like an afterthought.

In addition, Qutb was struck by American society and its politics. It was not difficult for Qutb to witness and probably experience America's endemic racism in 1948. In comparison to Egypt's traditional society, to him, Americans were awash in astounding sexual permissiveness. Qutb also began to realize America's international ambitions and global reach. He viewed America's power as an extension of the Western world's global dominance of smaller and more vulnerable nations.

While abroad, Qutb learned of Al-Banna's assassination in 1949, which was reported as good news in the US. Consequently, Qutb returned to Egypt with a kindred spirit for the Muslim Brotherhood and started working for the organization. Qutb's 
integration into the Brotherhood was seamless. He began by writing for its established journals, The Call, The Message, and The New Banner. From his post as a public intellectual, Qutb began to exert his influence on the Brotherhood's ideological message. In 1953, he was promoted to editor-in-chief of the Brotherhood's weekly publication, Ikwan al-Muslimoon. He then became the Brotherhood's ideological spokesperson when he was given posts in the Working Committee and the Guidance Council, the latter consisting of the upper echelon of the Brotherhood's members. Under Qutb's guidance, the Brotherhood began to publish extensively on religion and politics.

The close yet fraught relationship between the Brotherhood and Nasser's revolutionary party, the Free Officers, was forged in an overthrow of Egypt's monarch Farouk in 1952. All political parties were banned except for the Brotherhood. The group was popular as it was at the center of Islamic propagation; yet Nasser was supported by lay Egyptians and controlled the military. However, the pact between these groups had deep fissures. From the Brotherhood's perspective, Nasser and the Free Officers were not devout, but they sanctioned Nasser's revolutionary regime because they believed it was transitional. Consequently, at the behest of the Revolutionary Council, the Brotherhood's members refused a direct participatory role in government. The regime did not want to share political power as much as co-opt the Brotherhood.

A public dispute began between the regime and the Brotherhood when the organization openly criticized the Anglo-Egyptian pact reached on July 7, 1954. Specifically, criticism was lodged at the government because the British reserved the right to enter Egypt on the basis of security. Moreover, British troops would remain perpetually deployed around the Suez Canal. In October 26, 1954, there was an assassination attempt on Nasser, which was blamed on the Brotherhood. The regime cracked down on the organization: it was declared illegal, six members were sentenced to death, and an estimated 50000 members were arrested, including Qutb. In 1955, he was sentenced to 15 years of hard labor. Yet, soon after his prison sentence began, Nasser offered him both his freedom and a position in the Ministry of Education, conditional on Qutb's official request for a pardon. Qutb replied: 'I am surprised at people who ask the oppressed to beg for pardon and mercy for the oppressor. By God, if a few words of apology can save me from death on the gallows, I shall not do it, and will go before my Lord in a condition that I am wellpleased with Him and He with me' (1977 [1993], p. vi). Astonishingly, the offer was repeated various times, and Qutb's response was again filled with conviction, 'If I am imprisoned justly, then I accept my punishment as just and right, but if unjustly, then I cannot bow down pleading for mercy before injustice and error' (ibid., p. vii).

Qutb remained in prison until 1964. Early on, he was tortured and harassed, but was left alone for the majority of his sentence. This solitary time allowed Qutb to devote himself completely to the study of the Qu'ran and his multivolume work, In the Shade of the Qu'ran. In 1965, Qutb was freed by request of the president of Iraq, Abd Al-Salam Arif, who was on a state visit in Egypt. However, in less than a year, he was arrested once again, on trumped-up charges of terrorism and sedition, which were predicated on Nasser's belief that the Brotherhood was plotting to assassinate him. A special military tribunal tried Qutb in April 1966 and sentenced him to death. He was hanged on August 29, 1966.

\section{SAYYID QUTB'S IDEOLOGICAL PRINCIPLES}

Qutb spent the last decade of his life on an exegetical study of the Qu'ran from which his novel understanding of jahiliyyah emerged. However, this idea must be understood 
in the context of a number of religious-ideological concepts that undergird his philosophy. He drew on two important ideas, tasawwur (conception) and tawhid (oneness of God). Tasawwur is a comprehensive interpretation of being, which for Muslims includes the divine, the totality of the universe, and the singular worldly being, or man. Through tasawwur individuals learn their proper place within the interrelatedness of all beings and what differentiates those things. Qutb writes:

Islam is the religion of unity in this great universe, a unity which comprises all elements, from a single particle to the most advanced species of sophisticated life. ... There is unity among all living beings, all species, all generation; in fact, everything encompassed by existence. (1977 [1993], p. 6)

An understanding of the unity of the universe leads to the foremost article of Muslim faith: tawhid, which, once understood, beseeches the believer to organize his life in accordance with divine will. This idea denotes the singularity and oneness of God, and consciousness of this idea moves the believer to an acceptance of the absolute sovereignty of God. Qutb understands tawhid as an organizing principle for society that shapes his understanding of the practical dimensions of hakimiyyah and jahiliyyah. By functioning as a theological and social concept, tawhid guides the believer to renounce alternative sources of religious doctrine and political legislation. As a result, Qutb's Islamic reform takes on a universal and revolutionary form, specifically by exhorting Islam as a practical movement that applies to all humanity, as God is the only deity in the totality of life and this includes government and legislation (Wagemakers 2012, p. 61). When a society recognizes a multiplicity of authoritative systems such as religion, philosophy, and politics, this plurality divides and destroys systems of thought and social order: the God-given versus manmade. For Qutb, the West is beleaguered by an identity crisis of its own making. Scripture was its original source of knowledge, but the source splintered and migrated into rationalism, empiricism, and materialism, specifically Marxism (Bergesen 2008, p. 17).

Qutb contrasts the idea of the West as a set of fractured systems with nizam (order), which he views as an abstract force that regulates all of life. Nizam is a complex whole with the potential to be connected to particular systems such as the ethical, political, social, and international systems. As such, several nizams are included in the complex whole (Shepard 1989, p. 34). Ideas such as tawhid and nizam enabled Qutb to distinguish between Islam and jahiliyyah (the state of ignorance of God). Qutb understood true religion as the activity of the believer in correspondence with nizam and tawhid, which contrasts with Christian faith that depends on a particular kind of rational understanding, since obedience to God comes from a greater knowledge of God.

Qutb argued against the privileged position of religious groups, philosophers, theologians, and jurists. In his book Milestones, Qutb writes that 'to establish the rule of Allah on earth is not to give some consecrated people - the priest - the authority to rule ... nor to appoint some spokesmen of Allah as rulers, as is the case in a theocracy' (1964 [1990], p. 47). Qutb viewed the distinction between human and religious knowledge as a false one because the latter was built on the intrusion of philosophy into religion.

What kind of knowledge is possible in Islam? Qutb's anti-rationalism leads him to characterize knowledge of Islam as something that is not metaphysical or ideal in a Hegelian sense. Islam as nizam is not open to epistemological inquiry; human reason cannot know nizam. Neither philosophy nor science can understand Islam. Rather, knowledge of Islam depends on tacit knowledge or a sense of circumspection, which can only result in the appropriate acceptance of the sovereignty of God. 
In short, knowing Islam requires an appropriate consciousness. A believer is liberated from a secular form of thought and is in a mode of awareness in relation to Islam, in which the faith is an organic and dynamic entity independent of human thought. Islam as a movement synthesizes the universe, the divine, and the worldly. In the world, Islam is manifested in the particulars that constitute the whole of Muslim life, including the commitment of all Muslims who unite idea and action in their worship of God. Qutb's foundational views of religion animate his discussion of jahiliyyah. By casting religion into a comprehensive set of free-standing concepts, free from the errors of human comprehension, Qutb establishes grounds for the idea of jahiliyyah and his repudiation of both Western and tainted Muslim society and thought.

Most commonly, jahiliyyah is referred to as an 'age of ignorance' that defined Arabian society prior to the Prophet Muhammad's founding of Islam; a society characterized by a stiff resistance to the Prophet's monotheism. However, specifically, jahiliyyah spans the period of Arab cultural development from about AD 525 to precisely AD 622. Most importantly, in its Quranic context, 'the meaning of the word jahiliyyah denotes very specifically "the era during which the Arabians had no knowledge of Allah, the One and Only God of the Scriptures"' (Seeman 1966, pp. 188-189).

In Qutb's reinterpretation of the Qu'ran, he draws on a more nuanced meaning of jahiliyyah that does not necessarily indicate a specific historical epoch but instead refers to a reality that Muslims have faced throughout all history, in which Islam is threatened by ignorance and barbarism. Qutb cites the Qu'ran 5:50: 'Do they seek a jahiliyyah judgment, but who can give better judgment than God?' Qutb was not the first Islamic thinker who interpreted jahiliyyah through the lenses of the modern age.

Abul A'la Maududi (1903-1979), was one of the first Islamic thinkers to develop a political vision of Islam and construct a plan of social action to bring his vision to fruition (Nasr 1996, p. 3). He greatly influenced Qutb by his critique of Western culture and redefinition of Islam to mean a complete submission to Allah. He anticipated Qutb's idea of jahiliyyah by dividing Islam into 'real' and 'deceptive.' In addition, he viewed philosophy, culture, customs, mysticism, and mores that had developed over the centuries as impure accretions; thus, he 'did not view Islamic history as the history of Islam but as the history of un-Islam or jahiliyyah' (ibid., p. 60). Qutb, however, advanced the idea to a more nuanced and radicalized form as he extended the idea to mean both un-Islamic and non-Islamic societies.

\section{HAKIMIYYAH AND JAHILIYYAH}

By jahiliyyah, Qutb simply means the decision to choose human sovereignty over God's: 'it is neither a particular period in time, before or after Islam, not a particular place, race or state or society. It is, rather, a condition of any time and place where Allah is not held to be the highest governmental and legal authority' (Khatab 2006a, p. 3). There is a consensus that in English the Quranic meaning of hakimiyyah should be translated as: 'Sovereignty in which rests the highest legal and governmental authority' (Khatab 2002 p. 146). ${ }^{1}$ Qutb agrees with the Quranic meaning of the word, which is significant to his ideology because he emphasizes the political meaning of hakimiyyah; "Allah is the only "Hakim" or Sovereign and He has the right to legislate

1. The translation was carried out by the Supreme Sunni Council and Supreme Shi'i Council of Lebanon, and revised by Muhammad Zayid. 
and ordain the programme of human life' (ibid., p. 147). It is through the lenses of hakimiyyah that Qutb understands Islam, which leads to his sharp division between Islam and jahiliyyah.

Jahiliyyah results in the error of deifying human beings by elevating reason to the place of God. By ignoring God's revelation, man rebels 'against the sovereignty of God on earth' (Qutb 1964 [1990], p. 8). The sovereignty of human beings is predicated on the ascription of human sources of knowledge - philosophical, theological, and political - to privileged positions that decide on the verity and place of religion. Qutb describes the elevation of man-made ideas to the status of the divine as shirk: 'associating false gods with Allah' (ibid., p. 73). Consequently, human-based sovereignty lends itself to submission of the human will to human laws, which precludes the proper obedience to God's will and divine law.

In practice, hakimiyyah is a government and society that follows shariah. For Qutb the method of arriving at a government that obeys shariah is not as important as whether the government remains faithful to shariah. An Islamic political theory rests on the justice of the rulers, obedience on the part of ruled, and consultation between ruler and ruled (ibid., p. 120). Qutb writes, 'the love of the Divine Law, shariah, should be a consequence of pure submission to Allah and of freedom from servitude to anyone else. The laws of His creatures can hardly be compared to the laws given by the Creator' (ibid., p. 75). It is a problem for Muslims when the government departs from Islamic law.

Qutb insists on the adherence to divine will and sharply contrasts human and Islamic law, which is the eternal will of God and is manifested in the shariah. Yet what precisely is shariah, and how does the historical and sociological understanding of this idea differ from Qutb's? Shariah developed several hundred years after the Prophet Mohammed's death in $632 \mathrm{CE}$ as the Islamic empire expanded to the edge of North Africa in the West and to China in the East. Shariah is derived primarily from the Qu'ran, and sunnah, which are the hadiths (sayings), practices, and teachings of the Prophet Mohammed. In addition, the consensus of the Muslim community plays a role in defining shariah.

The sunnah plays an important role in Islam, as it provides both an explanation and a supplement to the Qu'ran. From a sociological perspective, the hadith and sunnah evolved over time to suit demographic, economic, and political conditions of Muslims that vary greatly from one sect to another, each crediting different sources of the hadith as legitimate. On account of this variability, different schools of Islamic thought have developed over time: the Sunni schools, Hanbali, Maliki, Shafi'i, Hanafi; and the Shiite school, Ja'fari.

For Qutb, shariah as the 'spirit of Islam' is an idea that overrides the view that shariah is defined by its historicist character. The 'spirit of Islam' countenances a specific religious experience, which opposes Islamic jurisprudence that relegates Islam to positive law. Qutb parses out this difference in Social Justice in Islam:

No renaissance of Islamic life can be affected purely by law or statute, or by the establishment of a social system on the basis of the Islamic philosophy. Such a step is only one of the two pillars on which Islam must always stand in its construction of life. The other is the production of a state of mind imbued with the Islamic theory of life, to give permanence to external forces leading to this form of life, and give coherence to all social, religious, and civil legislation ... hence Islamic legislation is more akin to ecclesiastical ordinance because it depends on religious belief. (1953 [2000], pp. 202-203)

The 'spirit of Islam' is active in all spheres of life and society; as such, shariah cannot be relegated to jurisprudence. Rather, Islamic jurisprudence must grow naturally 
from Islam's 'physical and natural structures' (Khatab and Bouma 2007 p. 84). Qutb sees shariah as much more than a code of social and religious laws; as the 'spirit of Islam,' shariah is a complete way of life. Due to this natural and organic view of Islamic society and law, Qutb opposes the idea that Islamic probity should be reached by imposing a stringent code of Islamic law on believers and non-believers.

How does the 'spirit of Islam,' embodied by shariah law, actually work? The answer to this question brings us back to Qutb's distinction between the organic understanding of Islam versus scientific and rational perspectives of manmade law. A true believer does not need to use a rationalizing and scientific process to understand the world; he possesses a circumspect understanding of the world and his place in it through the practice of Islam. Lived experience provides him with that circumspect understanding such that he is aware of his duties and obligations. Islamic law does not require coercion and a didactic approach; rather, it depends on the believer's right state of consciousness.

On closer inspection, Qutb's critique of rationality fails to address its tacit use among believers when interpreting religion and choosing among different sects. Thus, followers of Islam must 'rationalize' religion in one of two ways. First, they participate vicariously in the rationalizing process of interpreting Islam by claiming allegiance to religious leaders who use reason to interpret the faith. In addition, they make use of some type of rationality when choosing among competing interpretations. Qutb's distinctions between rationality and a hermeneutic of practice depend mostly on his methodology of interpreting the Qu'ran, which he sees as best understood concretely and comprehensively without speculation and antecedents (Judy 2004, p. 137).

Yet this method is problematic, as social scientists of Islam have pointed out, because the faith is a 'discursive tradition' that has evolved over time to suit the practices of institutions and communities (Haj 2008, p. 4). As Mohamed Ayoob (2008) has argued, modern Islamists reinvent tradition in order to dehistoricize Islam so as to purge it from impurities and accretions, which they consider as among the reasons for its decline (p. 2). Qutb's spurning of rationality has had a powerful effect on modern Islamists. Both well-known and lesser groups have taken his views to heart. In an attempt to purge what they believe to be a decadent form of Islam, they seek pious isolation from their society (Calvert 2010.) As such, human interpretation is seen as the bane of Islam leading to a radical rejection of Islamic schools of thought.

Although Qutb accepts the historicity of Islam, he does not quite do justice to its dialectic between scripture and reality. This sociological perspective explains how Islamic thinkers continually reinterpret Islam, specifically scripture, in order to meet their political and cultural circumstances. Qutb sees such rationalization as an attempt to subordinate shariah to fiqh (Islamic jurisprudence), which privileges the idea that fiqh is influenced by the personal and social environment of the past (Khatab 2006b, p. 39). For Qutb, the problem with socio-historical interpretations of Islam is that they reduce religion to its historicity, which deprecates the role of revelation. For Qutb, human reason (al-aql) is only free to confirm revelation; it does not stand outside of or judge revelation (ibid., p. 87).

Qutb understands shariah law as coeval with the 'spirit of Islam,' and he concludes that any rejection of hakimiyyah is tantamount to jahiliyyah. Thus, for him, jahiliyyah has primordial meaning and is not a mere superficial term to discriminate Muslims from non-Muslims. Rather, it is an idea that invokes Quranic elements and the notion of the eternal. To be in jahiliyyah is a human act that amounts to a principled rejection of God. The acceptance of human sovereignty is an act of usurping power. As such, it not only refutes God's divinity but grants his power to human systems. Jahiliyyah is 
evidenced in the social and political life of non-Muslim society in every age, from the Prophet to the present. What is the standard by which Qutb diagnoses a society as jahili? He writes: 'People - in any time and any place - are either governed by God's shariah - entirely, without any reservations - accepting it and submitting to it, in which case they are following God's religion, or they are governed by a shariah invented by humans' (Shepard 2003, p. 524). As such, Islamic law has a subaltern position in nominally Muslim - that is, impurely Muslim - societies, since jahiliyyah exists in every polity that accepts human sovereignty as its guiding principle.

Qutb's concern with human sovereignty can perhaps be better understood by juxtaposing another champion of overarching sovereignty, Thomas Hobbes. Hobbes thinks of sovereignty in secular terms; it is the solution to the problem of multiple independent wills and consciences that make it nearly impossible to create stable institutions and collective action. Only an artificial person, the sovereign, who is absolute and listens to no higher power, can solve the inevitable dilemmas caused by individuals who act on passions and their private judgments. Hobbes's starting point is the artful nature of the human being, which can imitate God by producing an 'artificial animal' (Hobbes 1996, p. 9).

What Hobbes essentially means is that the human being is a material being and can use reason to construct the state and the citizen in order to limit unbounded freedom. Human beings are capable of such ingenuity because they are complicated animals who combine sense perception and reason. Human art allows one to not only imitate nature but go beyond it. A product of such art, the state is intended to protect the individual and does this through the idea of sovereignty, which is yet another artifice. Qutb argues against Hobbes's notion of secular sovereignty. Hobbes derives the idea of a secular authority by considering the starting material conditions of human beings. From there he tries to moderate the larger ambitions of more belligerent types. Although the material world is never transcended, Qutb argues that Islam is a liberating force, which can be attained once individuals accept that Allah is the only sovereign.

Qutb's understanding of freedom is quite different from the Western understanding of the term. For Qutb, the acceptance of Islam liberates the individual from the passions (fear of death) and reliance on reason that Hobbes thinks are central to solving the problem of politics (Judy 2004, p. 121). According to Hobbes, people's passions mechanistically direct their actions; it is 'a general inclination of all mankind, a perpetuall and restlesse desire of Power after power, that only ceaseth in Death' (Hobbes 1996, p. 70). The moral conundrum that Hobbes must solve is how the initial appetitive desire becomes a boundless desire to rule vaingloriously over others in the natural state, as all others compete and are driven by the fear of violent death. The state, an institution of the sovereign power, essentially deprives humans of their ubiquitous irrationality for pride, ambition, and vanity (Strauss 1963, p. 13). In addition, the erection of the sovereign power inhibits the irrepressible liberty of the human being in the state of nature.

In Social Justice in Islam, Qutb expresses a much loftier conception of human freedom than does Hobbes:

Islam approaches the question of freedom from every angle and from all points of view; it undertakes a complete emancipation of conscience. It does not only deal with spiritual values or only with economic values, but with both together. It recognizes the practical reality of life and equally the capacities of the soul; it attempts to awaken in human nature the highest desires and to evoke the loftiest abilities, thus bringing that nature to complete freedom of conscience. (1953 [2000], p. 67) 
Qutb agrees with Hobbes about the historical character of human beings (Judy 2004, p. 130). Like Hobbes, he acknowledges that human drives and passions can easily dictate behavior. Despite this basic similarity, Hobbes's natural understanding of man leads to the liberal and secular view of freedom of conscience. Unlike Qutb's view, the liberal view includes deeply held secular convictions, such as equal respect, separation of church and state, and state neutrality with regard to religions. In the liberal tradition, freedom of conscience requires that each individual's religious choices and criticisms of established doctrines remain free and open. In practice, the secular state must always protect the tolerant alternative for the sake of a peaceful co-existence among different sects. Qutb's freedom of conscience is inconsistent with the liberal view, since it does not embrace constraint. Rather, freedom of conscience means the ability to freely choose Islam as it should be observed. It is unlikely that Qutb would embrace criticism of what he believes is a genuine Islamic doctrine.

Based on his idea of hakimiyyah, Qutb articulates a philosophical understanding of jahiliyyah. This broad idea means more than just a pre-Islamic historical epoch to describe both the non-Muslim world and any nominally Muslim people that reject God's sovereignty. According to Sayed Khatab (2006a), Qutb's idea of jahiliyyah 'is a comprehensive concept that can exist in any sphere of human conduct, in any society where Islamic law is not implemented' (p. 137). Consequently, Qutb viewed not only the West, but Egyptian society as well, as being in a state of jahiliyyah since Nasser's government was a secular nationalist dictatorship.

In Qutb's political thought, jahiliyyah can refer to either Muslim or non-Muslim societies. Jahili society can be a mix of religious and antireligious groups, modern or traditional, authoritarian or liberal. In sum, jahiliyyah divides the world between Islamic society and jahili societies. This dichotomy might seem oversimplified, but Qutb takes particular care to explain the complexity of jahili societies, especially why they tend to perpetuate themselves. These active entities operate under their own logic, which is strengthened by a set of practices, beliefs, and values. As functional systems, jahili societies create cooperation among individuals and loyalty to their moral and political doctrines. The dynamic nature of a jahili society enables its survival because it demands both human and structural agents to defend its preservation.

Qutb's account of jahili society as a dynamic and active force in no way praises that society's strength. Rather, he seems to raise alarm for how deeply jahiliyyah can embed itself institutionally and psychologically. These societies induce their people to love it before anything else. Moreover, jahiliyyah establishes both habits of mind and heart, appeals to self-interest and peoples' passions, raises human thought to the highest standard, and makes the people sovereign. No wonder Qutb saw America as a quintessential jahili society. Although the US's superior scientific and material progress generates great power and affluence, its moral standards continuously move toward more debased tendencies, such as the eroticization of women:

The American girl is well acquainted with her body's seductive capacity. She knows it lies in the face, and in expressive eyes, and thirsty lips. She knows seductiveness lies in the round breasts, the full buttocks, and in the shapely thighs, sleek legs and she knows all this and does not hide it. (Qutb 1951 [2000], p. 22)

Although resolute and full of vigor, Qutb describes jahili societies as intrinsically flawed, morally obtuse, and, due to their refutation of the divine, interminably ill-guided. They are predicated on a philosophic and scientific understanding of humanity, which inevitably produces an atomistic view of the human being and 
anthropocentric view of the universe. Conversely, Islam seeks a harmonious agreement between human nature and the universe. Politically, jahili societies are built on secular concepts and base passions. For example, communism centers on notions of class conflict and economic subsistence, Roman society was rooted in greed and race, and the modern European empires were grounded in oppression and exploitation (Qutb 1964 [1990], pp. 40-41). Only Islam countenances a society based on a universal creed, which Qutb does not identify strictly as a pan-Arab identity; his idea of community takes priority over any nationality.

Qutb's idea of jahiliyyah seeks to invert the Western view that the world is divided between developed states and the developing world. In Qutb's lifetime, Islamic countries were perceived to suffer from political, economic, and social backwardness. Yet he observes the reverse, as current jahili societies will become completely atheist. Thus, he sees greater backwardness in the deficit of spiritual values. The West has forgotten morality in its quest for ever greater material progress. Jahiliyyah and Islam can never coexist: 'Islam cannot accept any compromise with jahiliyyah, either in its concept or in the modes of living derived from this concept. Either Islam will remain, or jahiliyyah; Islam cannot accept or agree to a situation which is half-Islam and halfjahiliyyah. ... Command belongs to Allah, or else to jahiliyyah. The Shari'ah of Allah will prevail, or else people's desires' (ibid., p. 112).

\section{JAHILIYYAH AND JIHAD}

Despite the allure of jahiliyyah, Islamic society must counteract such elements. As such, it must be revolutionary. About Islamic society Qutb writes, 'It should enter the battlefield with a determination that its strategy, social organization, and interpersonal relationships will be firmer and more powerful than the existing jahili system' (ibid., p. 36).

In this last section I take a close look at Qutb's book Milestones (1964 [1990]) and the prologue of In the Shade of the Qur'an (1979 [2008], Volume 7, Surah 8, Al-Anfal). The latter, a 30-volume commentary on the Qu'ran, is Qutb's magnum opus and a key text for Islamists from the Philippines to Morocco, from Africa to Europe, and on to the diaspora in North Africa and South America (Toth 2013, p. 81). The last of the books published in Qutb's lifetime, the hugely successful Milestones was released in 1964. Sayed Khatab informs us that Milestones is a critical work in Qutb's corpus for two reasons: 'it is widely read and considered one of the most important reasons behind the verdict of the Military court against Qutb; [and] in this book, the motivational character of the concepts of jahiliyyah was reshaped into a plan meant to establish an Islamic society' (Khatab 2006a, p. 168).

Qutb is very precise about jihad in his work In the Shade of the Qur'an. He sees Islam itself as a movement and as an approach that confronts and acts to oppose jahiliyyah. Although his call to action is vague, specifically with regard to who are the specific actors of confrontation and how it will work, he is explicit that Islam must confront its opposition on two fronts:

It presents its arguments and proofs to correct concepts and beliefs; and it strives with power to remove the systems and authorities that prevent people from adopting the right beliefs, forcing them to follow their errant ways and worship deities other than God Almighty. (Qutb 1979 [2008], p. 46)

Islam is a revolutionary movement that seeks to abolish systems of oppression and, thus, change the environment for believers and nonbelievers alike. For Qutb, the 
ultimate goal is a universal liberation of man from authorities who are not God and an acceptance of God's sovereignty over the universe and everything in it (ibid., p. 48). Thus, the Islamic revolution is all-encompassing and world-wide. Although he reiterates that Islam strikes hard against jahili systems, he argues as well that Islam does not impose its beliefs on people. In genuine Islamic society, all are free to choose their faith, but they can never re-establish an alternative system of authority that contravenes Islam (ibid., p. 49). In this sense, he sees jihad as an internal struggle, in which war only plays a partial role. 'Struggle' is a more dynamic idea as it evokes sentiments, experiences, and hopes. The apologists who argue for jihad as a defensive war do not base their understanding on the Qu'ran but on international norms and the ends of modern warfare (Qutb 1964 [1990], p. 47).

Despite the obvious difference in Qutb's religious approach, his view of jihad echoes Marxist cries for a revolutionary movement that depends upon the existence of appropriate material conditions, and class struggle and consciousness. Qutb views calls for jihad as empty if they are not preceded by laying the groundwork for din (religion). Moreover, he criticizes Muslims who he believes use the term jihad in multiple and erroneous ways. The most prevalent misuse is the selective reading of the Qu'ran without any understanding of the stages of din. The jihadists who study Islam superficially read a few Quranic verses and believe they have a full understanding of din. About them, Qutb says, 'this group of thinkers, which is a product of the sorry state of the present Muslim generation has nothing but the label of Islam' (ibid., p. 46). In Milestones, Qutb discusses jihad in relationship to din (religion), which he describes as a movement and set of stages that uses practical means to confront jahiliyahh. Din is the catalyst for jihad because as a movement it must inevitably come into conflict with jahiliyyah (ibid., p. 45). This conflict emerges in two ways. First, jahiliyahh is diffused throughout all society: politics, science, and culture, all realms supported by knowledge and values. Islam is necessarily faced with the challenge of combating jahiliyyah in all these realms. As such, it must foster its ideas, values, and habits in a way that is stronger than jahili notions: 'it uses physical power and jihad to abolish organizations and authorities of the jahili system which prevent people from reforming their ideas and beliefs, forces them to follow deviant ways, and make them serve other humans instead of their Almighty Lord' (ibid., p. 45). In this stage of conflict, din enjoins Muslims to secure their freedom from human sovereignty by obeying God.

Jihad and its relationship to din are predicated on Qutb's understanding of freedom to worship Allah alone, which encompasses the implementation of shariah as well. In Qutb's more complex account, jihad is the phenomenon of struggle against the oppression of human systems on Islam for the sake of the believer's freedom to worship Allah alone: 'But life without belief is worthless, and life without freedom is degrading' (ibid., p. 131). When such freedom is in jeopardy, Muslims are obliged to challenge their oppressors on two fronts: intellectual and practical. The battle of ideas and values is fought through preaching; the restoration of freedom is achieved through an activist movement, and the political powers that 'force people to bow their will and authority, defying the commandments of Allah, and denying people the freedom to listen to the message of Islam' should be struck hard (ibid., p. 49).

Qutb finds his justification of jihad in his perception that illegitimate forms of authority have driven away Muslims from Islam. Again, Marxist overtones penetrate Qutb's ideas as he likens his position to the Marxist vanguard. It is the responsibility of a small minority 'to implement the Islamic declaration of man's liberation from all authority except that of God' (Qutb 1979 [2008], p. 54). Qutb justifies his 
proclamation for the observance of one overarching religion for everyone by saying that Islam is neither one faith among many nor should it be defined by any particular Muslim nation. One reason for his generalization is his attempt to move away from the perception of Islam as a kind of nationalism because he thinks it would limit the faith to a question of territory. Therefore, Islam as a form of nationalism narrows jihad to war strategy. For him, Islam is a universal cause, and as such jihad does not mean war but 'stands for exerting one's utmost endeavor to promote a cause' (ibid., p. 59). Yet, Qutb does not preclude the use of force. He quotes the Qu'ran on this point: 'Fight them, until there is no more oppression, and all submission is made to God alone' (ibid., p. 63).

Such is Qutb's endorsement of jihad. His is an uncompromising view that the believer must oppose jahiliyyah because it is the greatest threat to Islam. For Qutb, it is devouring Islamic society, and Muslims find themselves in beleaguered positions when trying to fight it. Islamic societies that embrace secularism and only pay lip service to religion are just as bad because they reduce Islam to a toothless set of duties and obligations. As William Shepard observes, Qutb assails the main secularist and modernist Muslim positions, 'those who respect religion or claim to follow shariah are particularly dangerous, for they put Islamic signs over the camps of depravity and decay ... even much of what we call Islamic culture, Islamic sources, Islamic philosophy, and Islamic thought is the product of this [present] jahiliyyah' (2003, p. 528).

\section{CONCLUSION}

The influence of Qutb on contemporary Islamic leaders and groups is drawn from his reinterpretation of jahiliyyah's deep and ongoing effects on Islam. For his adherents, it is unfathomable for Islam to accept and integrate into a system that is characteristically jahiliyyah. Thus, even liberal democratic movements that protect and recognize Islam as a religious practice but must constrain its full practice and societal implementation are not viable systems that Islam can work with. Given Qutb's unrelenting critique of modern Western systems and Islamic societies that turn away from Islam, it is difficult to see how such an ideology can exist within the bounds of a liberal democratic society, unless groups like the Muslim Brotherhood have lost interest in the revolutionary zeal of his ideas. However, if the tense political environment and renewed violence in Egypt today indicates anything, it is that the Muslim Brotherhood and other political actors have yet to settle their differences and compromise. The world is anxiously waiting to see if this political impasse is due to the growing pains of a new democracy learning to work together or if the Brotherhood, with power and opportunity, is bent on establishing the Islamic state it has promised its followers for so long.

Sayyid Qutb's political philosophy demands serious attention. His intimate acquaintance with Western thought and practice, multidimensional approach to religion and politics, and serious study of the Qu'ran, requires both advocates and critics to engage his works in a disciplined way. He elaborates complex religious, metaphysical, and political positions and it is impossible to give a full account of his ideas without paying attention to his whole corpus.

Upon reading Qutb's works, the reader finds an uncompromising view about the state of affairs for Islam in the modern age, which is due to his ominous beliefs about the Muslim past and future. His views, and those of his followers, threaten to plunge modern Islamists into dangerous and deadly confrontations between both Muslim and Western societies. It is difficult to imagine anything resembling traditional 
Western notions of democracy in Qutb's philosophy. To the extent that the Muslim Brotherhood moves forward on the basis of Qutb's ideology, the ultimate reconciliation between the Muslim Brotherhood and more secular aspects of Egypt's society appears unlikely.

\section{REFERENCES}

Armstrong, K. (2000), Islam: A Short History. New York, NY: Modern Library.

Ayoob, Mohammed (2008), The Many Faces of Political Islam: Religion and Politics in the Muslim World. Ann Arbor, MI: The University of Michigan Press.

Bergesen, A.J. (2008), The Sayyid Qutb Reader: Selected Writings on Politics, Religion, and Society. New York: Routledge.

Berman, P. (2003), The philosopher of Islamic terror. New York Times Magazine, March 23, available at: http://www.nytimes.com/2003/03/23/magazine/the-philosopher-of-islamic-terror.html? pagewanted $=$ all\&src $=$ pm.

Calvert, J. (2010), Sayyid Qutb and the Origins of Islamic Radicalism. New York: Oxford University Press.

Haj, S. (2008), Reconfiguring Islamic Tradition: Reform Rationality and Modernity. Stanford, CA: Stanford University Press.

Hobbes, T. (1996), Leviathan, edited by R. Tuck. Cambridge: Cambridge University Press.

Judy, R.A.T. (2004), Sayyid Qutb's fiqh al-waqui'i, or new realist science. Boundary 2, 31(2), 113-147.

Keddie, N. (1972), Sayyid Jamal ad-Din 'al-Afghani': A Political Biography. Berkeley, CA: University of California Press.

Keddie, N. (1983), An Islamic Response to Imperialism: Political and Religious Writings of Sayyid Jamal al-Din 'al-Afghani.' Berkeley, CA: University of California Press.

Khan, A.A. (2012), Muhammad Abduh's contribution to modernity. Asian Journal of Management Sciences and Education, 1(1), 63-75.

Khatab, S. (2002), Hakimiyyah and jahiliyyah in the thought of Sayyid Qutb. Middle Eastern Studies, 38(3), 145-170.

Khatab, S. (2006a), The Political Thought of Sayyid Qutb: The Theory of Jahiliyyah. New York, NY: Routledge.

Khatab, S. (2006b), The Power of Sovereignty: The Political and Ideological Philosophy of Sayyid Qutb. New York, NY: Routledge.

Khatab, S. and Bouma, G.D. (2007), Democracy in Islam. Routledge Studies in Political Islam, London: Routledge.

Moussalli, A. (1992), Radical Islamic Fundamentalism: The Ideological and Political Discourse of Sayyid Qutb. Beirut, Lebanon: American University of Beirut.

Nasr, S.V.R. (1996), Mawdudi and the Making of Islamic Revivalism. New York, NY: Oxford University Press.

Pargeter, Alison (2010), The Muslim Brotherhood: The Burden of Tradition. London: Saqi Books.

Qutb, S. (1951 [2000]). 'The America I have seen': in the scale of human values. America in an Arab Mirror: Images of America in Arabic Travel Literature - An Anthology. New York: Palgrave Macmillan.

Qutb, S. (1953 [2000]), Social Justice in Islam. Oneonta, NY: Islamic Publications International. Qutb, S. (1964 [1990]), Milestones. Indianapolis: American Trust Publications.

Qutb, S. (1977 [1993]), Islam and Universal Peace. Indiana: American Trust Publications.

Qutb, S. (1979 [2008]), In the Shade of the Qur'an, Prologue, Volume 7, Surah 8, Al-Anfal. The Spoils of War, edited by A.J. Bergesen. New York, NY: Routledge.

Rubin, B. (2010), The Muslim Brotherhood: The Organization and Policies of a Global Islamist Movement. New York: Palgrave Macmillan.

Sedgwick, M.J. (2010), Muhammad Abduh: Makers of the Modern World. Oxford: Oneworld Publications. 
80 Leadership and the Humanities, Vol. 2 No. 1

Seeman, K. (1966), Education in Islam, from jahiliyyah to Ibn Khaldun. The Muslim World, 56, $188-198$.

Shepard, William E. (1989), Islam as a 'System' in the later writings of Sayyid Qutb. Middle Eastern Studies, 25(1), 31-50.

Shepard, W.E. (2003), Sayyid Qutb's doctrine of jahiliyya. International Journal of Middle East Studies, 35, 521-545.

Strauss, L. (1963), The political philosophy of Thomas Hobbes: its basis and its genesis. Chicago: University of Chicago Press.

Toth, J. (2013), Sayyid Qutb: The Life and Legacy of a Radical Islamic Intellectual. New York, NY: Oxford University Press.

Wagemakers, J. (2012), A Quietist Jihadi: The Ideology and Influence of Abu Muhammad Al-Maqdisi. New York, NY: Cambridge University Press. 